\title{
Does commercialization of a non-timber forest product reduce ecological impact? A case study of the Critically Endangered Aquilaria crassna in Lao PDR
}

\author{
Anders Jensen and Henrik Meilby
}

\begin{abstract}
Aquilaria crassna, a tree species on CITES Appendix II and categorized as Critically Endangered on the IUCN Red List, is the main source of the highly valuable, fragrant and resinous agarwood that is extracted in forests in Southeast Asia, exported to East Asian and Arab countries, and used for a range of medicinal, aromatic and religious products. Based on interviews with local, non-local and foreign harvesters in Laos we examined the relationships between harvesters' daily net revenue from agarwood extraction, their degree of commercialization (i.e. their differential access to markets) and their ability to target harvesting towards the small fraction of trees that do contain commercial qualities and quantities of agarwood. For comparison we included data on number of trees felled during the most recent harvesting trip. The analysis showed that poor targeting ability and low degree of commercialization were associated with low daily net revenues, whereas good targeting ability and high degree of commercialization were associated with high daily net revenues. In the case of A. crassna in Laos it therefore appears that the activities of highly commercialized harvesters are less harmful to A. crassna populations than those of less specialized, local harvesters.
\end{abstract}

Keywords Agarwood, Aquilaria crassna, gaharu, Laos, non-timber forest product, NTFP, South-east Asia.

\section{Introduction}

Commercialization of non-timber forest products $U$ (NTFPs) is much celebrated, and researchers assiduously encourage coupling of concerns over rural livelihoods with concerns over conservation of biodiversity (Salafsky \& Wollenberg, 2000; Arnold \& Ruiz-Perez, 2001; Shackleton, 2001). Improved market access and increased value in trade, it is argued, will increase returns and employment opportunities, especially for poor and disadvantaged people. It may also create opportunities for conservation of ecosystems and individually valuable species. The idea is that demand for products from a forest environment will translate effectively into demand for forest (Belcher \& Schreckenberg, 2007). By simultaneously increasing cash

Anders Jensen (Corresponding author) and Henrik Meilby University of Copenhagen, Danish Centre for Forest, Landscape \& Planning, Rolighedsvej 23, DK-1958 Frederiksberg C, Denmark. E-mail anderslaos@yahoo.co.uk

Received 25 April 2007. Revision requested 26 July 2007.

Accepted 16 January 2008. income to rural communities and increasing value of forest and tree resources, commercialization is arguably a means to both forest conservation and livelihood improvement.

The literature is not devoid of case studies corroborating this optimism but examples of poorly profitable activities (Byron \& Arnold, 1999; Wunder, 1999; Neumann \& Hirsch, 2000) and destructive harvesting practices (Anderson \& Putz, 2002; Coomes, 2004; Ticktin, 2004) are of some concern. By analysing a number of cases with respect to ecological and socio-economic conditions and cultural factors, criteria have been identified for successful NTFP commercialization (Ruiz-Perez \& Byron, 1999; Marshall et al., 2003; Belcher et al., 2005; Kusters et al., 2006). However, Newton (2008) has cautioned that tree species are subjected to a variety of threats that often act in combination, e.g. conversion of forest to agriculture land, urban expansion, habitat fragmentation and use of fire.

With much evidence of poorer sections of the populations in developing countries being principally engaged in NTFP extraction (Neumann \& Hirsch, 2000), and a multitude of functions in rural livelihoods being fulfilled by NTFPs (Neumann \& Hirsch, 2000; Marshall et al., 2006), detrimental changes may occur in the wake of commercialization. Furthermore, there are numerous examples in which traditional producers and users of particular NTFPs are disadvantaged by commercialization (Belcher \& Schreckenberg, 2007). Also, higher resource scarcity and increased value of forest products may trigger differentiation processes and increase economic inequality (Angelsen \& Wunder, 2003). Hence, commercialization may not be a means to overcome poverty and income disparities but may rather exacerbate them, and may also put undue pressure on the resource.

It seems evident that differences occur with regard to NTFP harvesters' abilities to generate returns. In part this may be explained by differential access to markets, and in part by differences in ability to focus harvesting and extract products of high quality at low costs. In the case study reported here we examined whether the degree of commercialization of an NTFP can reduce ecological impact. We did this by analysing whether some harvesters have a better ability to target their harvesting so that it becomes less destructive and yields greater returns, and if this targeting ability is related to how commercial the harvesters are.

To answer these questions we make use of data collected in a country-wide harvest and trade survey conducted from February 2003 to March 2005 in Lao PDR (henceforth 
Laos) on agarwood, probably the most valuable NTFP (Yamada, 1995; Paoli et al., 2001; Wollenberg, 2001). Laos has one of Asia's poorest and most underdeveloped economies (World Bank, 2006) and is a prominent NTFP producer with great hopes for poverty alleviation through commercialization (Manivong, 2001; MAF, 2004; Foppes \& Ketphanh, 2005; Gansberghe, 2005).

\section{Agarwood}

Aquilaria crassna Pierre ex H. Lec. (Family Thymelaeaceae) is an upper understorey tree occurring in primary evergreen and semi-evergreen forests at altitudes from 600$1,400 \mathrm{~m}$. Agarwood or gaharu is a dark-coloured, fragrant resin that accumulates in roots, trunk and branches of the tree as nodules of varying age, shape, size and commercial quality. Agarwood is formed by the tree in response to injury if the primary mechanism, formation of phloem callus tissue, is inhibited (Nobuchi \& Siripatanadilok, 1991; Blanchette, 2003). The resinous agarwood acts as a chemical barrier to attacks by fungi and insects but under natural conditions it is not formed by all trees (Paoli et al., 2001).

Harvest and trade of agarwood include raw materials for distillation of essential agarwood oil, which is used for perfume in Arab countries, and unprocessed agarwood, which is used in medicinal, aromatic, ceremonial and religious preparations. For unprocessed agarwood old trade routes exist from range states in South-east Asia to consumers in the Arab world and in East Asian countries (Yamada, 1995; Barden et al., 2000).

The global demand rose sharply following the 1973 oil crisis, which raised purchasing power in Arab markets, and currently exceeds the available supply (Yamada, 1995; Barden et al., 2000; Zich \& Compton, 2001), which is limited because of the nature of the product. Intensive and destructive harvesting and reduction of habitat areas have led to international concern for the future of the species. This has resulted in listing of the genus Aquilaria on CITES Appendix II (CITES, 2005), and several species of Aquilaria are on the IUCN Red List (IUCN, 2007). A. crassna is categorized as Critically Endangered.

Commercialization of agarwood in Laos began 1975-1976 after the end of the Second Indochina War, and was started by Vietnamese veterans in the southern provinces. In the 1980 s harvesting spread to the whole country and increasingly involved Lao harvesters. In 1997 the first distillation plants were established by Lao wholesalers and by 1998-1999 the number of operating plants reached its maximum of 80 . Already in this phase there were signs of over-harvesting, and from 2003 the agarwood business entered a stage of decline. Domestication has not yielded commercial quantities of agarwood and it is doubtful whether it will (Jensen, 2004). All supplies are currently from natural forests.

\section{Methods}

In the harvest and trade survey the sampling of respondents followed a systematic approach of going backwards in the value chain. A census of all legal wholesalers $(n=45)$ and illegal wholesalers $(\mathrm{n}=10)$ in Laos led to interviews with a sample of agents $(n=41)$ and traders $(n=32)$, and again to interviews with samples of local harvesters $(\mathrm{n}=52)$, nonlocal harvesters $(\mathrm{n}=35)$ and foreign, i.e. Vietnamese, harvesters $(n=16)$. It emerged that interviews with leaders of harvesting groups were more effective than interviews with whole groups or individual members of harvesting groups. Consequently, the survey was conducted using semistructured interviews with group leaders. The interviews included both quantitative and qualitative questions. Based on interviews with the agents, traders and wholesalers, it is estimated that at the time of the survey the numbers of active harvesters were 350 Vietnamese, 1,600 professional, non-local (Lao) harvesters and 6,300 local, non-professional harvesters. Hence, the approximate sampling fractions were: Vietnamese 4.6\%, non-local 2.2\% and local harvesters $0.8 \%$.

Interviews were conducted at factory gates, en route, or in villages in three provinces: Saysomboun Special Zone, Sayabouri and Phongsali, which were the three main agarwood-supplying provinces in 2004. People were also interviewed in Pakkading district of Bolikhamsai province, which is the base for a large number of non-local harvesters and home to over half of the legally operating agarwood wholesalers in Laos. All interviews were conducted in Lao by AJ.

Harvesting return is defined as net revenue per harvester and is calculated as gross revenue per harvesting trip from sale of agarwood less the average costs per trip. Because of differences with regard to annual number of days spent on agarwood harvesting the daily net revenue is used as a measure of returns. This is estimated as net revenue per harvesting trip and harvester divided by the stated average duration of harvesting trips. All data refer to the year 2004, daily net revenue is denoted in Lao Kip (LAK), and the exchange rates of the currencies that agarwood is traded in are USD $1=$ LAK $10,500=$ THB 43 .

Commercialization is the integration of harvesters into markets. Agarwood is not traded in markets with a physical location but sold at distillation plants to wholesalers, or to mobile agents and traders. In (1) local markets agarwood is purchased by a wholesaler and his agents who hold de jure rights to purchase and process all wood harvested in districts covered by his business license, i.e. a monopsony. In (2) regional markets agarwood is sold to agents and traders from other provinces. These are either attached to a wholesaler or work independently. This sort of trade is in most cases illegal as it violates the legal monopsony. Illegal trade also takes place in (3) national markets where 
agarwood is sold to wholesalers, agents and traders in the capital Vientiane or in Pakkading district, and in (4) international markets where agarwood is taken to Vietnam and sold to Vietnamese traders. Revenue is expected to increase from (1) to (4) because of higher sales prices. Responses provided in the interviews indicated that harvesters often trade in more than one market.

In principle, harvesters could trade in all four markets but this rarely happens. To obtain a measure of the degree of commercialization we assigned the following additive scores: trading in local market yields a score of o, regional markets a score of 1 , and national and international markets a score of 2, i.e. harvesters are seen as more commercialized if they have access to national and international markets than if they are constrained to trade in local and regional markets. The equal scores assigned to international and national markets reflect the fact that these are both accessed by international traders and agents, for example from Singapore, Dubai and Japan, and that for most products the price levels are similar. The main reason for distinguishing between the two markets is that Lao harvesters sell their harvest in Laos only, whereas Vietnamese harvesters operate both in Lao and Vietnamese markets and often have access to lucrative market channels for high-value products.

Some harvesters buy from other harvesters to increase the quantity they can offer for sale to agents and wholesalers. Other things being equal, the larger the quantity offered, the higher the price. Hence, in our measure of degree of commercialization we assigned a score of 1 to harvesters who buy from other harvesters. Consequently, adding up the scores the degree of commercialization varies within the range $0-6$ and the maximum of 6 is obtained by harvesters who trade in regional, national (Lao) and international (Vietnamese) markets and buy from other harvesters.

Targeting ability is the ability of harvesters to determine if a tree is likely to contain agarwood in commercial qualities and quantities, and to decide with some confidence if a tree should be felled or not. For standing trees the presence of agarwood and its quality is assessed using several interrelated indicators: tree, stem and bark characteristics, phenology, wounding, presence of tree-boring insects, bore dust and ants, and various indicators that can be assessed after injuring the trees, e.g. black spots in the white sapwood. Trees with a diameter at breast height $(\mathrm{DBH})$ of $>50 \mathrm{~cm}$ have a high likelihood of containing agarwood but even trees of $10 \mathrm{~cm}$ DBH may contain agarwood. A binary variable, termed Predictor, was used to express whether the agarwood indicators were known to the respondent (Predictor $=1$ ) or not (Predictor $=0$ ).

To fell a tree takes 0.5-4 hours and it is therefore possible to increase the daily net revenue considerably by harvesting trees that contain high quality agarwood. Potentially harvesters with good targeting ability will therefore leave trees without commercial qualities and quantities of agarwood untouched, leading to less impact on the population of A. crassna. As an additional proxy variable for targeting ability we therefore used harvesters' estimate of the proportion of trees $(>10 \mathrm{~cm} \mathrm{DBH})$ in natural populations that are likely to contain agarwood of commercial interest. The higher the estimated Proportion, the greater the expected number of trees felled. The applied targeting ability measure was expressed as $(1+$ Predictor $) *(1-$ Proportion $) * 10$, yielding a value in the range $0-20$. High values of this measure indicate that harvesters know the agarwood indicators and realize that agarwood in commercial qualities and quantities is only found in a low proportion of the trees.

To check whether apparent targeting ability was consistent with actual tree felling behaviour, we made use of the fact that harvesters were asked about the number of trees felled by the group during the most recent harvesting trip. In the analyses we apply the number of trees felled per man and day, which is approximated by dividing the number of trees felled during the most recent trip by the average number of harvesters in the group and the average duration of harvesting trips.

The analysis of the relationships between targeting ability, number of trees felled per man and day, degree of commercialization and daily net revenue included graphical, correlation and regression analyses. Transformations were applied to ensure that the basic assumptions of linear regression were not violated.

\section{Results}

In Table 1 mean values and 95\% confidence intervals are given for the three main groups of harvesters and the four variables used in the analysis, and the amount of agarwood harvested in an average harvesting trip. Mean daily net revenues differ significantly between the three groups and so do their mean degree of commercialization and mean targeting ability (the $95 \%$ confidence limits do not overlap). With regard to the mean number of trees felled during the most recent trip there is no significant difference between foreign (Vietnamese) and non-local (Lao) harvesters but the mean for locals is significantly higher than those of foreign and non-local harvesters. There are no significant differences in amount harvested between the three groups, and amount harvested is not determining daily net revenue but rather the commercial quality of the wood.

Coefficients of correlation between the four original variables (Table 1) and the two transformed variables used in the regression analysis are given in Table 2. All correlations are significantly different from zero. High positive correlation is observed between daily net revenue, degree of commercialization and targeting ability, and the 
TABLE 1 Summary statistics for daily net revenue, degree of commercialization and targeting ability (see text for details) and number of trees felled and amount harvested on most recent trip with mean and 95\% confidence intervals (in parentheses).

\begin{tabular}{llllll}
\hline & $\begin{array}{l}\text { Net revenue } \\
\left(\text { LAK } 1,000 \mathrm{day}^{-1}\right)\end{array}$ & $\begin{array}{l}\text { Degree of } \\
\text { commercialization } \\
(\text { range 0-6) }\end{array}$ & $\begin{array}{l}\text { Targeting ability } \\
(\text { range 0-20) }\end{array}$ & $\begin{array}{l}\text { Number of } \\
\text { trees felled } \\
\left(\mathrm{man}^{-1} \mathrm{day}^{-1}\right)\end{array}$ & $\begin{array}{l}\text { Amount harvested } \\
\left(\mathrm{kg} \mathrm{man}^{-1} \mathrm{trip}^{-1}\right)\end{array}$ \\
Group of harvesters & $132.6(115.8-149.3)$ & $5.0(4.5-5.5)$ & $17.8(17.3-18.5)$ & $0.03(0.02-0.05)$ & $17.5(15.7-19.3)$ \\
Foreign $(\mathrm{n}=16)$ & $83.9(74.3-93.6)$ & $2.8(2.3-3.2)$ & $14.3(13.1-15.5)$ & $0.04(0.02-0.05)$ & $17.0(15.2-18.8)$ \\
Non-local $(\mathrm{n}=35)$ & $48.8(41.9-55.7)$ & $0.6(0.4-0.9)$ & $7.8(5.9-9.8)$ & $0.21(0.11-0.31)$ & $15.1(13.7-16.4)$ \\
Local $(\mathrm{n}=52)$ & & &
\end{tabular}

correlation between number of trees felled and other variables is negative. Compared with the original variables, daily net revenue and number of trees felled (NTF), the coefficients of correlation are greater for the transformed variables. As expected, the reciprocal number of trees felled, $1 /(\mathrm{NTF}+1)$, is positively correlated with other variables.

A plot of the mean number of trees felled versus the mean targeting ability for each degree of commercialization (o...6) shows that harvesters characterized by a low degree of commercialization (0-1) are also those who have poor targeting ability and have felled many trees during the most recent trip (Fig. 1). However, for degrees of commercialization of 2-6 the differences are small. Targeting ability varies considerably among harvesters who have a low degree of commercialization (o-1) but harvesters with a high degree of commercialization are characterized by limited variation with regard to targeting ability (Fig. 2).

In Table 3 regression results are given for two models in which the dependent variable is the logarithm of daily net revenue. In model (a) there is a strongly significant relationship between daily net revenue and targeting ability and degree of commercialization. In model (b) targeting ability is replaced by the reciprocal number of trees felled. The coefficient of determination of model (b) is slightly lower and the parameter estimate of the reciprocal number of trees felled is not significant but the sign of the parameter estimate is positive, as expected. The variability in the number of trees felled per man and day was presumed to be high and thus a strong relationship with daily net revenue was not anticipated. Fig. 3 shows the distribution of the residuals for the two models and, although the variation may appear to be greater for small predicted values than for larger ones, the overall pattern seems acceptable. Daily net revenue increases with increasing targeting ability and with increasing degree of commercialization (Fig. 4a), and also increases with decreasing number of trees felled (per man and day) and with increasing degree of commercialization (Fig. 4b).

\section{Discussion}

In the great amount of literature published on NTFPs there is a gap in research on ecology and harvesting impacts as well as in availability of baseline data (Neumann \& Hirsch, 2000; Belcher \& Schreckenberg, 2007). Here we have related quantifiable indicators of harvesters' knowledge and experience to data on returns from harvesting. To our knowledge, this is the first attempt to do so.

Harvesters from Laos participated willingly in interviews and shared their knowledge and experience with enthusiasm. Ethnic Vietnamese harvesters were more cautious and interviews were conducted as informal chats on agarwood business but still with successful completion of the interviews. Nevertheless, data from approximately 30 interviews, almost the same number from each of the three main groups, had to be discarded because of interruptions. Further studies on impact of agarwood harvesting on conservation of $A$. crassna would need to include direct observation and participation in harvesting trips, as done by Soehartono \& Newton (2001), but preferably including a larger number of trips.

Disparities with regard to daily net revenue from agarwood harvesting are substantial, with foreign harvesters' returns up to three times those of local harvesters (Table 1). Even with the comparatively low daily net revenues observed for local people, findings from other studies

TABLE 2 Coefficients of correlation between daily net revenue, degree of commercialization, targeting ability and number of trees felled per man and day on most recent trip (NTF; Table 1) and $\ln$ (daily net revenue) and the reciprocal of NTF.

\begin{tabular}{|c|c|c|c|c|}
\hline Variable & Degree of commercialization & Targeting ability & NTF & $1 /(\mathrm{NTF}+1)$ \\
\hline Daily net revenue & $0.68^{\star \star *}$ & $0.63^{\star * *}$ & $-0.27^{\star \star}$ & $0.32^{\star \star}$ \\
\hline $\ln$ (daily net revenue) & $0.68^{\star * *}$ & $0.73^{* * *}$ & $-0.34^{\star * *}$ & $0.40^{* * *}$ \\
\hline Degree of commercialization & & $0.69^{* * *}$ & $-0.34^{* * *}$ & $0.43^{* * *}$ \\
\hline Targeting ability & & & $-0.44^{* * *}$ & $0.51^{\star * *}$ \\
\hline
\end{tabular}

${ }^{* *}, \mathrm{P}<0.01 ;{ }^{* * *}, \mathrm{P}<0.001$ 


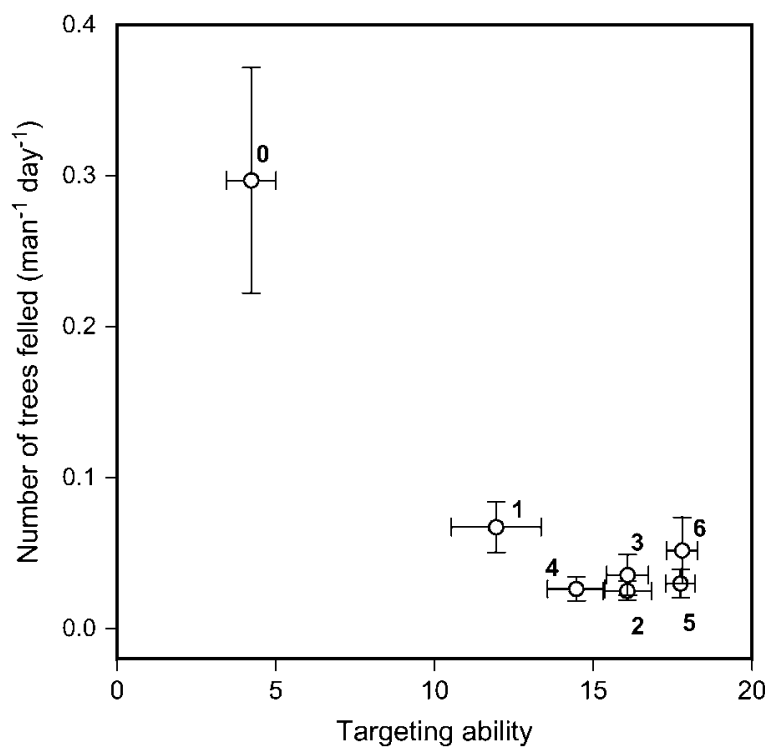

Fig. 1 Number of trees felled versus targeting ability for each of the seven degrees of commercialization $(0$, low ... 6 , high; see text for details). Values for both variables are mean $\pm \mathrm{SE}$ (bidirectional bars).

indicate that the dependence on agarwood as a source of cash income can be significant in Lao rural areas. Estimates range from 20 to $70 \%$ of total cash income for households (Brahmi \& Phoumphone, 2003; Alton \& Rattanavong, 2004; Yamada et al., 2004). Marked differences were observed with regard to degree of commercialization between the three groups of harvesters interviewed (Table 1). Similarly, considerable differences between the three groups of harvesters were observed with regard to the applied proxy of targeting ability.

The data collected do not allow us to estimate the distribution of harvests to different markets and product categories. However, it seems, based on the interviews, that high value/low quantity products are sold in regional, national and international markets, whereas low quality/ high quantity products are mainly sold in local markets. This means that market access is likely to correlate with the value of products sold, explaining part of the effect of market access on returns.

Daily net revenue was also positively related to targeting ability (Tables 2 \& 3, Fig. 4). To make harvesting profitable only trees containing agarwood should be felled, thus

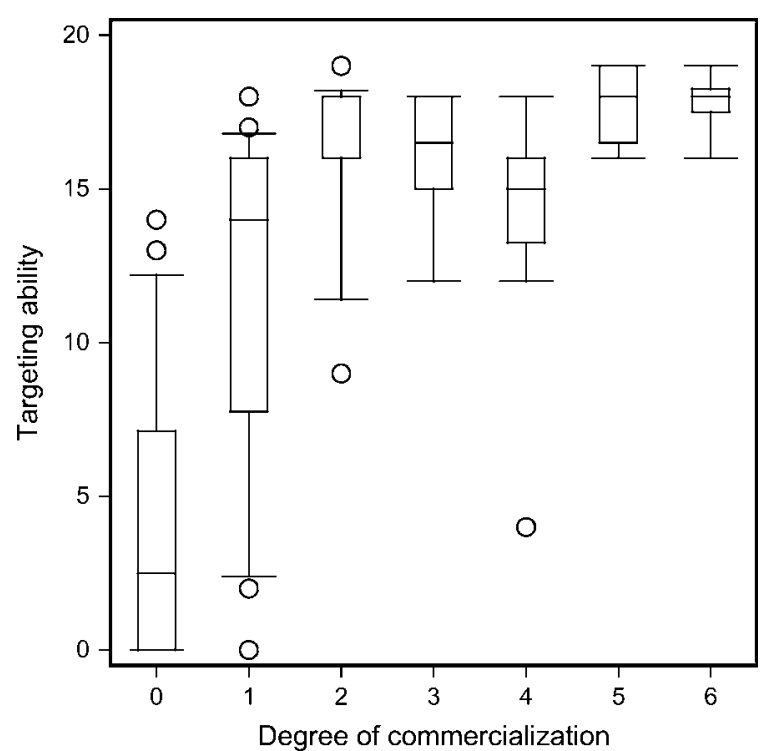

Fig. 2 Box-plot illustrating the distribution of targeting ability for each of the seven degrees of commercialization $(0$, low ... 6 , high; see text for details). Percentiles are are 10th, 25th, 50th, 75 th and 90th. Circles indicate observations below the 10th or above the 90th percentile.

saving time and allowing harvesters to search larger areas. To increase revenue, highly skilled harvesters are compelled to fell only the small number of trees containing high quality agarwood. These products are sold in regional, national and international markets, explaining why degree of commercialization and targeting ability are closely related (Table 2 , Fig. 2). It is likely, therefore, that harvesting by experienced and knowledgeable harvesters will leave populations relatively intact except for removal of a few, large trees. By contrast, inexperienced harvesters are likely to be indiscriminate in their harvesting, leaving only a few trees intact and spending considerable time felling and chopping up trees that do not yield agarwood. Unfortunately, no data are currently available to corroborate these suppositions.

The diameter distribution is certainly affected by harvesting. Experienced harvesters will tend to fell all trees encountered with $\mathrm{DBH}>50 \mathrm{~cm}$ as well as fruit-bearing trees because size and fruiting are some of the external signs of agarwood formation. The long-term genetic impacts may be severe and need to be assessed. Such an assessment should also include the profuse natural regeneration

TABLE 3 Linear regressions expressing logarithmic daily net revenue (ln(DNR); LAK man $^{-1}$ day $^{-1}$ ) as a function of (a) targeting ability and degree of commercialization, and (b) the reciprocal of number of trees felled (NTF) and degree of commercialization, with parameter estimates and standard errors (in parentheses).

\begin{tabular}{llllllll}
\hline & Dependent & & Root & & \multicolumn{2}{l}{ Independent variables } \\
\cline { 5 - 8 } Model & variable & $R^{2}$ & mean SE & Intercept & $1 /(\mathrm{NTF}+1)$ & Targeting ability & Degree of commercialization \\
\hline (a) & $\ln (\mathrm{DNR})$ & 0.59 & 0.390 & $10.31^{\star * *}(0.078)$ & & $0.04430^{\star * *}(0.0081)$ & $0.1096^{\star * *}(0.028)$ \\
(b) & $\ln (\mathrm{DNR})$ & 0.48 & 0.438 & $10.05^{\star * \star}(0.346)$ & $0.6482^{\mathrm{NS}}(0.394)$ & & $0.1981^{\star * *}(0.025)$ \\
\hline
\end{tabular}

***, P $<0.001$; NS, P $>0.05$ 

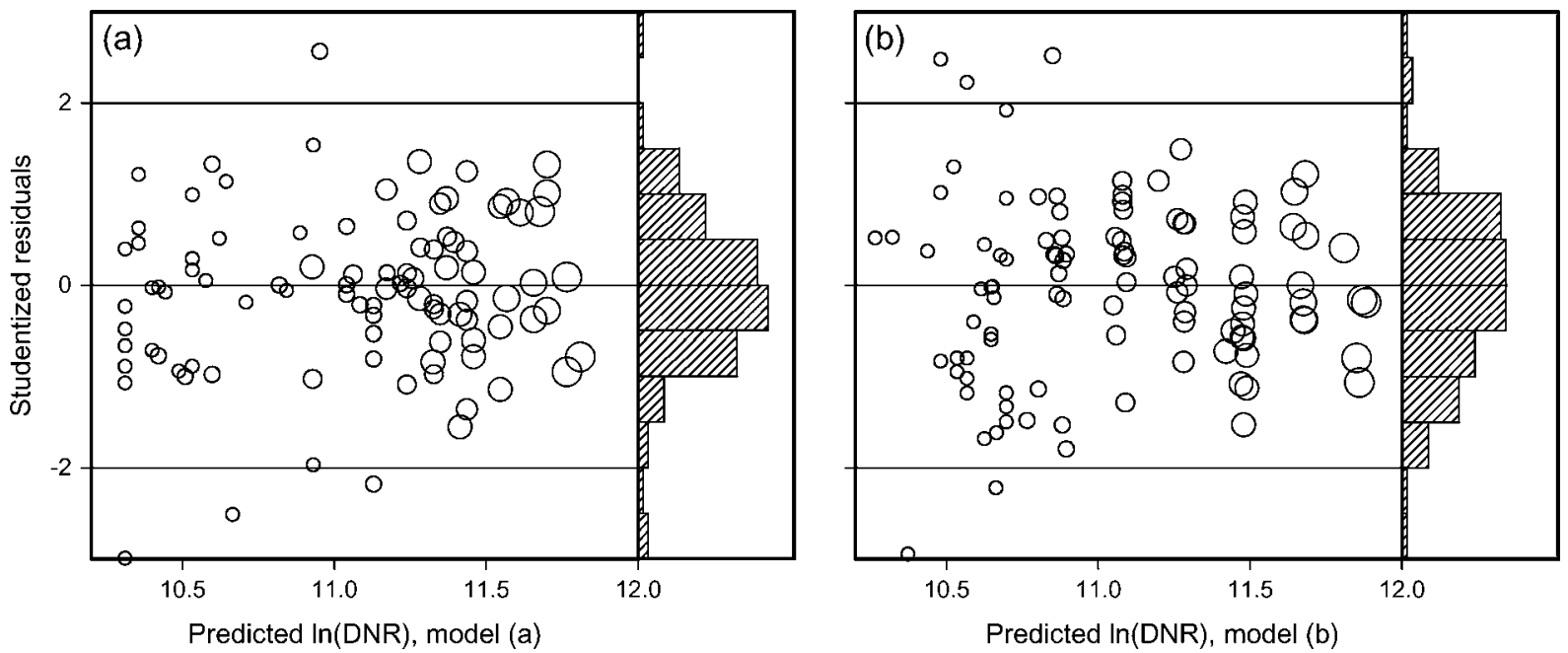

FIG. 3 Studentized residuals versus predicted logarithm of daily net revenue, $\ln (\mathrm{DNR})$, for models (a) and (b) of Table 3 . Diameter of circles is proportional to degree of commercialization; histogram gives the frequency distribution of the residuals.

observed during an inventory in moderately and heavily harvested sites (AJ, pers. obs.) and the prevention of natural regeneration when harvesters dig up roots of old trees.

The two variables used to create the applied measure of targeting ability are related to number of harvesting days in the previous 5 years, and considerable differences exist between new entrants, i.e. local people, and full-time harvesters with much experience (Jensen \& Meilby, 2006). To make harvesting profitable and to stay in business, harvesters have to learn either from other harvesters and/or by trial and error, and gradually become more experienced, have more success finding trees with agarwood, and become better able to predict if it is worthwhile felling individual trees. When agarwood-forming trees become increasingly harder to find, experienced and knowledgeable harvesters will abandon A. crassna habitats. This is likely to happen long before the last tree is felled (Vayda \& Walters, 1999).

Part of the learning process required to increase returns is related to gaining better access to profitable markets by building up a network with agents and traders, i.e. becoming more commercialized. In this study this is evidenced by the strong relationship between daily net revenue, targeting ability and degree of commercialization.
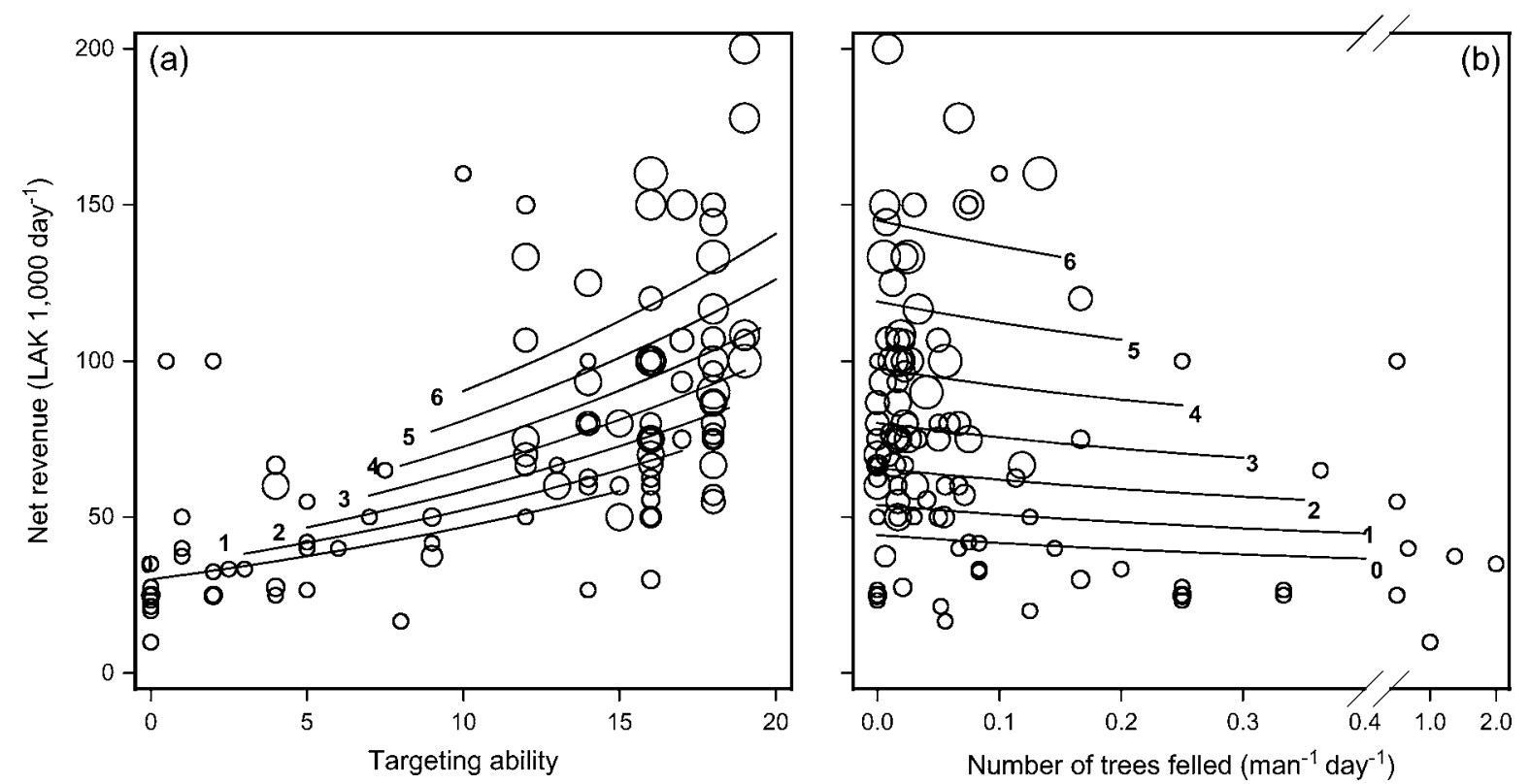

FIG. 4 Net revenue (LAK 1,000 day ${ }^{-1}$ ) versus (a) targeting ability and (b) number of trees felled $\left(\mathrm{man}^{-1}\right.$ day $^{-1}$ ). Diameter of circles is proportional to degree of commercialization. Lines indicate values predicted by the regression models in Table 3 (models (a) and (b), respectively, for (a) and (b)) for each of the seven degrees of commercialization ( 0 , low ... 6 , high; see text for details). The curvature is caused by the logarithmic transformation. 
In conclusion, this case study of $A$. crassna and agarwood in Laos shows that it is possible to reduce ecological impact and increase revenues simultaneously by targeting harvesting to the few, valuable trees in a population when access to markets is in place. This information could form the basis of training and knowledge transfer for the benefit of both harvesters and conservation.

\section{Acknowledgements}

Comments and suggestions from two anonymous reviewers and A.C. Newton greatly improved this article. We are indebted to Habib Mohammad Choudhry, Phoukeo Chanhsomphou and Christopher Hoeth for their guidance and assistance in arranging interviews, transport and other logistics. We also thank our research assistants Uthay Inthoulay, Vongvilay Vongkhamsao and Khamtanh Khamphanh from the Forestry Research Centre in Vientiane, Lao PDR for their effort and enthusiasm, and last but not least, we owe a debt of gratitude to the great number of harvesters who shared their knowledge and understanding. The study was funded by the University of Copenhagen and the Danish Ministry of Foreign Affairs. The fieldwork was carried out in affiliation with the National Agriculture \& Forestry Research Institute in Lao PDR.

\section{References}

Alton, C. \& Rattanavong, H. (2004) Service Delivery and Resettlement: Options for Development Planning. Final Report Livelihoods Study, Lao/o3/Ao. UNDP/ECHO, Vientiane, Lao PDR.

Anderson, P.J. \& Putz, F.E. (2002) Harvesting and conservation: are both possible for the palm, Iriartea deltoidea? Forest Ecology and Management, 170, 271-283.

Angelsen, A. \& Wunder, S. (2003) Exploring the Forest Poverty Link: Key Concepts, Issues and Research Implications. Occasional Paper no. 40. CIFOR, Bogor, Indonesia.

Arnold, J.E.M. \& Ruiz-Perez, M. (2001) Can non-timber forest products match tropical forest conservation and development objectives? Ecological Economics, 39, 437-447.

Barden, A., Anak, N.A., Mulliken, T. \& Song, M. (2000) Heart of the Matter: Agarwood Use and Trade, and CITES Implementation for Aquilaria malaccensis. TRAFFIC International, Cambridge, UK.

Belcher, B., Ruiz-Perez, M. \& Achdiawan, R. (2005) Global patterns and trends in the use and management of commercial NTFPs: implications for livelihoods and conservation. World Development, 33, 1435-1452.

Belcher, B. \& Schreckenberg, K. (2007) Commercialization of non-timber forest products: a reality check. Development Policy Review, 25, 355-377.

Blanchette, R.A. (2003) Agarwood Formation in Aquilaria Trees: Resin Production in Nature and How It Can Be Induced in Plantation Grown Trees. Notes from presentation at First International Agarwood Conference, Ho Chi Minh City, Vietnam, 10-15 November 2003. The Tropical Rainforest Project, Ho Chi Minh City, Vietnam.
Brahmi, A. \& Phoumphone, K. (2003) Study on Local Coping Mechanisms in Disaster Management: Case Studies from the Lao PDR. Unpublished Report, Concern, Vientiane, Lao PDR.

Byron, R.N. \& ARnOLD, J.E.M. (1999) What futures for the people of the tropical forests? World Development, 27, 789-805.

CITES (2005) Fifteenth Meeting of the Plants Committee. Amendments to Appendix II of CITES. Unpublished Report, CITES Geneva, Switzerland.

Coomes, O.T. (2004) Rain forest 'conservation-through-use'? Chambira fibre extraction and handicraft production in a land-constrained community, Peruvian Amazon. Biodiversity and Conservation, 13, 351-360.

Foppes, J. \& Ketphanh, S. (2005) Non-timber forest products for poverty reduction and shifting cultivation stabilization in the uplands of the Lao PDR. In Poverty Reduction and Shifting Cultivation Stabilization in the Uplands of Lao PDR: Technologies, Approaches and Methods for Improving Upland Livelihoods Proceedings of a Workshop held in Luang Prabang, Laos PDR, January 27-30, 2004 (eds B. Bouahom, A. Glendinning, S. Nilsson \& M. Victor), pp. 181-193. National Agriculture and Forestry Research Institute, Vientiane, Lao PDR.

Gansberghe, D. (2005) Agriculture and forestry in the National Growth and Poverty Eradication Strategy. In Improving Livelihoods in the Uplands of Lao PDR (eds A. Glendinning, D. Clayton, M. Dubois, M. Fernandez \& S. Nilsson), pp. 3-11. Unpublished Report, National Agriculture \& Forestry Extension Service/National Agriculture \& Forestry Research Institute/ National University of Laos, Vientiane, Lao PDR.

IUCN (2007) 2007 IUCN Red List of Threatened Species. IUCN, Gland, Switzerland. Http://www.iucnredlist.org/ [accessed 17 January 2008].

Jensen, A. (2004) Domestication of Aquilaria spp. and rural poverty socio-economic and genetic aspects of the planting boom in the 'Wood of the Gods'. In Poverty Reduction and Shifting Cultivation Stabilization in the Uplands of Lao PDR: Technologies, Approaches and Methods for Improving Upland Livelihoods - Proceedings of a Workshop held in Luang Prabang, Laos PDR, January 27-30, 2004 (eds B. Bouahom, A. Glendinning, S. Nilsson \& M. Victor), pp. 233-239. National Agriculture and Forestry Research Institute, Vientiane, Lao PDR.

Jensen, A. \& Meinby, H. (2006) The good, the bad and the ugly: income determinants and a typology of commercial agarwood harvesters in Lao PDR. Proceedings of the Biennial Meeting of the Scandinavian Society of Forest Economics, Uppsala, Sweden, May 8-11, 2006. Scandinavian Forest Economics, 41, 121-129.

Kusters, K., Achdiawan, R., Belcher, B. \& Ruiz-Perez, M. (2006) Balancing development and conservation? An assessment of livelihood and environmental outcomes of non-timber forest product trade in Asia, Africa, and Latin America. Ecology and Society, 11(2), article 20. Http://www.ecologyandsociety.org/vol11/ iss2/art20/ [accessed 22 February 2008].

MAF (2004) Forestry Strategy to the Year 2020 (FS2020) of the Lao PDR. Ministry of Agriculture and Forestry, Vientiane, Lao PDR.

Manivong, K. (2001) Non-wood Forest Products Study in Lao PDR. Unpublished Report, EC-FAO Partnership Programme Information and Analysis for Sustainable Forest Management: National and International Efforts in South Asia and Southeast Asia, Vientiane, Lao PDR.

Marshall, E., Newton, A.C. \& Schreckenberg, K. (2003) Commercialization of non-timber forest products: first steps in analysing the factors influencing success. International Forestry Review, 5, 128-137.

Marshall, E., Schreckenberg, K. \& Newton, A.C. (2006) Commercialization of Non-timber Forest Products - Factors Influencing Success. Lessons Learned from Mexico and Bolivia and 
Policy Implications for Decision-makers. UNEP World Conservation Monitoring Centre, Cambridge, UK.

Neumann, R.P. \& Hirsch, E. (2000) Commercialization of Nontimber Forest Products: Review and Analysis of Research. CIFOR, Bogor, Indonesia.

Newton, A.C. (2008) Conservation of tree species through sustainable use: how can it be achieved in practice? Oryx, 42, 195-205.

Nobuchi, T. \& Siripatanadilok, S. (1991) Preliminary observation of Aquilaria crassna wood associated with the formation of aloeswood. Bulletin Kyoto University Forest, 63, 226-235.

Paoli, G.D., Peart, D.R., Leighton, M. \& Samsoedin, I. (2001) An ecological and economic assessment of the nontimber forest product gaharu in the Gunung Palung National Park, West Kalimantan, Indonesia. Conservation Biology, 15, 1721-1732.

Ruiz-Perez, M. \& Byron, N. (1999) A methodology to analyze divergent case studies of non-timber forest products and their development potential. Forest Science, 45, 1-14.

Salafsky, N. \& Wollenberg, E. (200o) Linking livelihoods and conservation: a conceptual framework and scale for assessing the integration of human needs and biodiversity. World Development, 28, 1421-1438.

ShaCKLETON, C.M. (2001) Re-examining local and market-oriented use of wild species for the conservation of biodiversity. Environmental Conservation, 28, 270-278.

Soemartono, T. \& Newton, A.C. (2001) Conservation and sustainable use of tropical trees in the genus Aquilaria II. The impact of gaharu harvesting in Indonesia. Biological Conservation, $97,29-41$.

Ticktin, T. (2004) The ecological implications of harvesting non-timber forest products. Journal of Applied Ecology, $41,11-21$.

VAyda, A.P. \& Walters, B.B. (1999) Against political ecology. Human Ecology, 27, 167-179.
WollenberG, E.K. (2001) Incentives for collecting gaharu (fungalinfested wood of Aquilaria spp.; Thymelaeaceae) in East Kalimantan. Economic Botany, 55, 444-456.

World Bank (2006) Lao PDR Economic Monitor. World Bank, Vientiane, Lao PDR. Http://siteresources.worldbank.org/LAOPRDEXTN/Resources/LaoEconomicMonitorNov2006.pdf [accessed 20 September 2007].

W under, S. (1999) Promoting Forest Conservation Through Ecotourism Income? A Case Study from the Ecuadorian Amazonian Region. Occasional Paper no. 21. CIFOR, Bogor, Indonesia.

YAMADA, I. (1995) Aloewood forest and the maritime world. Southeast Asian Studies, 33, 463-468.

Yamada, K., Y An a gisa w a, M., Kono, Y. \& Nawata, E. (2004) Use of natural biological resources and their roles in household food security in northwest Laos. Southeast Asian Studies, 41, 426-442.

Zich, F. \& Сомттоn, J. (2001) The Final Frontier: Towards Sustainable Management of Papua New Guinea's Agarwood Resource. TRAFFIC Oceania/WWF South Pacific Programme, Wollongong, Australia.

\section{Biographical sketches}

ANDERS JENSEN's experience includes conservation of biodiversity and genetic resources, forest sector planning and policy, project cycle management, seed supply, institutional aspects of sustainable forest management, and financial management. His research interests include socio-economics of biodiversity conservation, participatory forest management, inventory of non-timber forest products, and value chain analysis. HenRik Meilby's research interests cover a wide range of topics, from ecological and biomechanical aspects of the structure, design, growth, and development of trees and forests to economic optimization of management strategies, dynamics resulting from such strategies, and methods used to solve the related planning problems. He has been involved in capacity building projects in Bolivia since 2001 and Nepal since 2004. 